\title{
Toothpick test: a methodology for the detection of RR soybean plants ${ }^{1}$
}

\author{
Teste do palito: metodologia para detecção de plantas de soja RR
}

\author{
Fabiana Mota da Silva ${ }^{2}$, Sandra Helena Unêda-Trevisoli ${ }^{3 *}$, Otávia Tiago Villela ${ }^{3}$, Dilermando Perecin ${ }^{4}$ e Antonio \\ Orlando Di Mauro ${ }^{3}$
}

\begin{abstract}
Due to the large increase in the area cultivated with genetically modified soybean in Brazil, it has become necessary to determine methods that are fast and efficient for detecting these cultivars. The aim of this work was to test the efficiency of the toothpick method in the detection of RR soybean plants, as well as to distinguish between cultivars, for sensitivity caused by herbicide. Ten transgenic soybean cultivars, resistant to the active ingredient glyphosate, and ten conventional soybean cultivars were used. Toothpicks soaked in glyphosate were applied to all the plants at stage V6 and evaluations were made at 2, 4, 6, 8 and 10 days after application (DAA). The effects of the glyphosate on the cultivars, and the symptoms of phytotoxicity caused in the transgenic plants were evaluated by means of grading scales. The toothpick test is effective in identifying RR soybean cultivars and also in separating them into groups by sensitivity to the symptoms caused by the glyphosate.
\end{abstract}

Key words: Glycine max. Phytotoxicity. Glyphosate. Toothpick method. Herbicide.

RESUMO - Devido ao grande aumento da área cultivada com soja geneticamente modificada no Brasil, faz-se necessária a determinação de métodos que sejam rápidos e eficientes na detecção dessas cultivares. O objetivo deste trabalho foi testar a eficiência do método do palito na detecção de plantas de soja RR, bem como distinguir as cultivares quanto à sensibilidade causada pelo herbicida. Foram utilizadas dez cultivares de soja transgênica, resistentes ao ingrediente ativo glifosato, e dez cultivares de soja convencional. Palitos de dente embebidos em glifosato foram aplicados em todas as plantas em estádio V6 e as avaliações foram realizadas aos 2; 4; 6; 8 e 10 dias após a aplicação (DAA). Os efeitos da ação do glifosato nas cultivares e os sintomas de fitotoxicidade, ocasionados nas plantas transgênicas, foram avaliados por meio de escalas de notas. O teste do palito é eficiente para identificar as cultivares de soja RR e, além disso, separálas em grupos de sensibilidade aos sintomas causados pelo glifosato.

Palavras-chave: Glycine max. Fitotoxidade. Glifosato. Método do palito. Herbicida.

\footnotetext{
DOI: $10.5935 / 1806-6690.20150024$

*Autor para correspondência

${ }^{1}$ Recebido para publicação em 31/01/2014; aprovado em 21/01/2015

Trabalho de Pesquisa financiado pela FAPESP

${ }^{2}$ Departamento de Produção Vegetal, Melhoramento Genético de Plantas, Universidade Estadual Paulista Júlio de Mesquita Filho, São PauloSP, Brasil, motaagro@ hotmail.com

${ }^{3}$ Departamento de Produção Vegetal, Melhoramento Genético de Plantas, Universidade Estadual Paulista Júlio de Mesquita Filho, São PauloSP, Brasil, strevisoli@fcav.unesp.br, otavia_agrouel@hotmail.com,orlando@fcav.unesp.br

${ }^{4}$ Departamento de Ciências Exatas, Estatística Experimental/Universidade Estadual Paulista Júlio de Mesquita Filho, São Paulo-SP, Brasil, perecin@fcav.unesp.br
} 


\section{INTRODUCTION}

Brazil is the second largest producer of soybeans, with a production of about 90 million tonnes (COMPANHIA NACIONAL DE ABASTECIMENTO, 2014). Currently in the country, cultivation of the soybean (Glycine max L. Merrill.) covers an area of 27 million hectares, of which $91.1 \%$ (24.60 million hectares) is given over to growing genetically modified soybean (CÉLERES, 2013).

A characteristic of Roundup Ready (RR) soybean is a tolerance to the active ingredient glyphosate. In sensitive plants, glyphosate is a herbicide which acts by inhibiting the enzyme 5-enolpyruvylshikimate-3phosphate synthase (EPSPS), obstructing the formation of amino acids essential for protein synthesis (QUERCI et al., 2010). In RR soybean, glyphosate tolerance is acquired by recombination with the CP4-EPSPS gene, derived from the Agrobacterium bacteria (PADGETTE et al., 1995).

There are several methods for detecting soybean which is tolerant or intolerant to glyphosate. These are based on the cellular or molecular characteristics of the genotypes and differ in their levels of sophistication, completion time and cost (CONCEIÇÃO; MOREIRA; BINSFELD, 2006; HEINZ; VIEGAS NETO; VALENTE, 2011).

The tests most commonly used in detecting RR soybean are specific "kits" for detecting proteins, and are fast and simple. Lateral flow immunoassay (LFI) detects the CP4-EPSPS protein, and the ELISA test (immunochromatographic assay, based on antigenantibody binding reactions) detects specific proteins contained in the seeds of RR soybean (CONCEIÇÃO; MOREIRA; BINSFELD, 2006 ). Another widely used technique is PCR (Polymerase Chain Reaction), which distinguishes soybean genotypes by specific sequences of recombinant DNA, thereby ensuring qualitative and quantitative results (CUNHA et al., 2005). Usually carried out in high-tech laboratories, the PCR technique requires sophisticated equipment and qualified personnel.

The detection of genetically-modified soybean is necessary in conventional breeding programs, in the identification of homozygous strains and to identify transgenic cultivars obtained by backcrossing. Detection of these plants by the use of glyphosate is more difficult in the field or in the greenhouse. Some authors report problems of phytotoxicity, reduction in productivity and the presence of herbicide residue in plants and seeds, often causing losses in the commercial value and quality of the product (BERVALD et al., 2010; REIS et al., 2010). The selection of individual transgenic plants therefore requires methodologies that are easy, of low cost and not aggressive to nearby plants.

No reports are to be found in the literature of studies aimed at assisting breeding programs in the identification of RR soybean, either in the field or in the greenhouse. Considering the advance of transgenic soybean crops in the country and in the world, the use of efficient, rapid and inexpensive detection techniques, whose results can be reproduced, is appropriate.

The aim of this study was to test the efficiency of the toothpick method in the detection of soybean cultivars which are tolerant to glyphosate, as well as to differentiate the cultivars as to sensitivity caused by the herbicide.

\section{MATERIAL AND METHODS}

The work was carried out at the Department of Plant Production, of the School for Agricultural and Veterinary Sciences, at the Jaboticabal Campus of UNESP, in the state of São Paulo, Brazil, in a greenhouse at an average temperature of $25^{\circ} \mathrm{C}$ and a relative humidity of $60 \%$.

The experiment was conducted in the agricultural year of 2012, in a completely randomised design (CRD), where the treatments consisted of ten conventional soybean cultivars (FD 39, CD 217, CD 205, IAC Foscarim, FT Crystalina, BRS 183, BRS Sambaíba, BRS Conquista, BRS Tucunaré and BRS Renasença) and ten RR soybean cultivars (BMX Potência, TMG 4001, NA 6411, BRS Juliana, P 98Y70, CD 242, TMG 315, SYN 9078, M 8336 and $M$ 7908), with 10 replications. Each lot consisted of one pot with three plants, giving a total of 30 plants per treatment. The cultivars were planted in $5 \mathrm{~L}$ polyethylene pots containing approximately $4 \mathrm{~kg}$ of substrate, which was made up of soil and vermiculite in the proportion of $4: 1$. The plants were irrigated daily, and management of pests and diseases performed when necessary, following the Empresa Brasileira de Pesquisa Agropecuária (2011) recommendations for soybean crops.

The commercial glyphosate (Roundup Ready®) used in the study contains $648 \mathrm{~g}$ of glyphosate isopropylamine salt or $480 \mathrm{~g}$ of equivalent glyphosate acid. To apply the product to the plants, round wooden toothpicks were employed, which had been previously sterilised in an autoclave for 20 minutes at $120{ }^{\circ} \mathrm{C}$ and at $1 \mathrm{~atm}$, cut in half horizontally with a blade and then immersed for 24 hours in a solution of glyphosate. The toothpicks were inserted into the stems of the plants between the leaf nodes, at growth stage V6 (30 days after emergence), and remained on the stems until the end of the evaluations. For purposes of control, some plants were selected on which the test was done using a toothpick with no glyphosate solution. Before inserting the toothpick, all the trifoliate leaves of the plant were counted.

Evaluations were made at 2, 4, 6, 8 and 10 days after application (DAA) of the toothpicks, with the effects 
of the glyphosate action on the plants being evaluated by use of a diagrammatic scale with ratings from 1 to 9 .

As no specific methodology for grading the effects of the herbicide was found in the literature, the rating scale used was adapted from the Huang and Hartman (1998) model, used for identifying disease symptoms in plants. On the adapted scale, $1=$ no symptoms, 2 = development of such symptoms as yellowing or wilting, $3=$ death of between 1 and $10 \%$ of the leaves, $4=$ death of between 11 and $20 \%$ of the leaves, $5=$ death of between 21 and $30 \%$ of the leaves, 6 $=$ death of between 31 and $50 \%$ of the leaves, $7=$ death of between 51 and $70 \%$ of the leaves, $8=$ death of between 71 and $100 \%$ of the leaves and $9=$ dead plant.

The symptoms of phytotoxicity caused by the glyphosate among the soybean cultivars were also evaluated using a rating diagram (Figure 1) proposed by Reis et al. (2010), where $0=$ absence of symptoms on the affected leaf area, $2=$ from 1 to $20 \%, 3=$ from 41 to $60 \%, 4=$ from 61 to $80 \%$ and $5=$ more than $81 \%$ of the leaf area affected. Using this diagram the percentage of total leaf area affected by the symptoms was established, and the set of leaves evaluated (MARTINS et al., 2004).

The results were submitted to variance analysis and a test of means with the help of the Statistical Analysis System (2008) software, version Windows 9.2. The means of the treatments were compared by t-test.

To ensure the accuracy and efficiency of the toothpick test, the transgenic plants were detected in the laboratory by the PCR technique, which distinguishes soybean genotypes by the presence of specific sequences of transgenic DNA.

DNA extraction was carried out on young leaves using the CTAB extraction method described by Ferreira and Grattapaglia (1995). DNA extraction was repeated three times for each cultivar, giving a total of 60 reactions.

To identify the RR soybean, specific oligonucleotides were used which pair up in the sequence RR-F TGATGTGATATCTCCACTGACG and RR-R TGTATCCCTTGAGCCATGTTGT in the direction 5' $\rightarrow$ ', which encodes the EPSPS coding region. The sequence has a fragment size of $172 \mathrm{pb}$ (MARCELINO; GUIMARÃES; BARROS, 2007).

The PCR reactions were run in a final volume of $25 \mathrm{uL}$, containing $0.2 \mathrm{mM}$ of each dNTP, $1 \mathrm{U}$ Taq DNA polymerase, $6 \mu \mathrm{M}$ of each oligonucleotide, $300 \mathrm{ng}$ DNA template, $1 \mathrm{x}$ buffer of the Taq DNA polymerase enzyme and $1.5 \mathrm{mM} \mathrm{MgCl}_{2}$. The reactions were carried out in a Programmable Thermal Controller PTC-100 TM thermocycler (MJ Research), with an initial denaturation period of seven minutes at $94{ }^{\circ} \mathrm{C}$, followed by 35 polymerisation cycles $\left(94{ }^{\circ} \mathrm{C}\right.$ for $30 \mathrm{~s}, 55^{\circ} \mathrm{C}$ for $30 \mathrm{~s}$, and $72{ }^{\circ} \mathrm{C}$ for $30 \mathrm{~s}$ ) and an additional period of polymerisation of seven minutes at $72{ }^{\circ} \mathrm{C}$. The amplified fragments were separated by electrophoresis on $1.5 \%(\mathrm{w} / \mathrm{v})$ agarose gel containing $10 \mathrm{ng} / \mu \mathrm{l}$ ethidium bromide immersed in a $1 \mathrm{X}$ TBE buffer $(90 \mathrm{mM}$ TrisBorate, 0.5 M EDTA pH 8.0) and visualised with a UV transilluminator.

Figure 1 - Rating diagram for identification and quantification of the symptoms of phytotoxicity
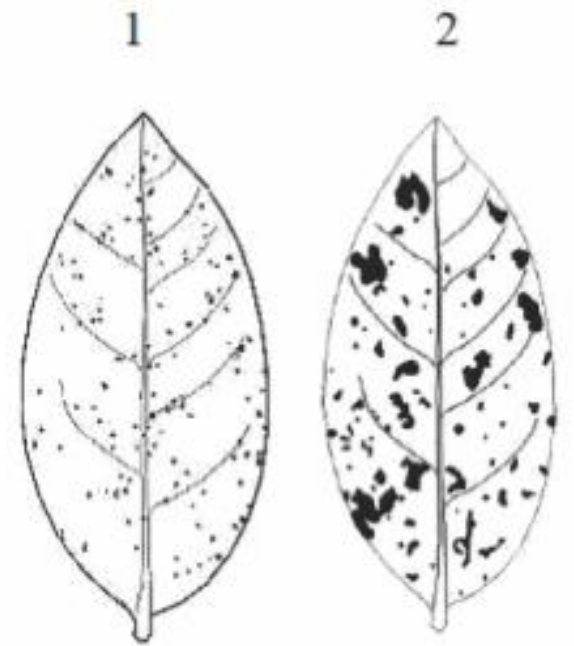

$1-20 \%$
$21-40 \%$

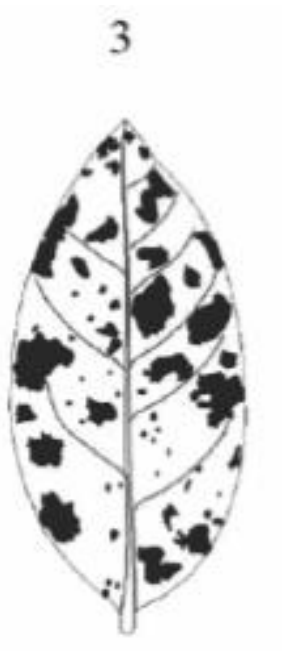

$41-60 \%$

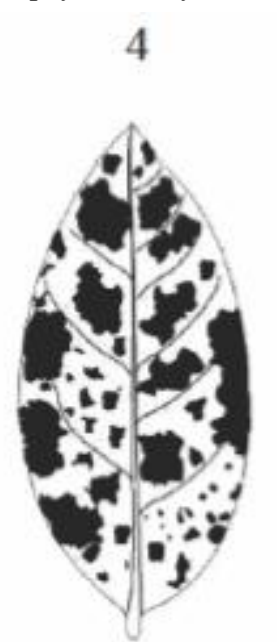

$61-80 \%$

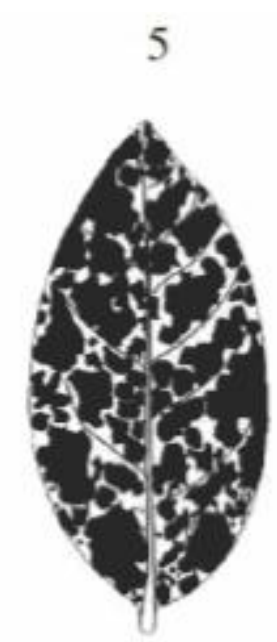

$81-100 \%$ 


\section{RESULTS AND DISCUSSION}

The toothpick method made it possible to differentiate between the transgenic soybean cultivars (BMX Potência, TMG 4001, NA 6411, BRS Juliana, P 98Y70, CD 242, TMG 315, SYN 9078, M 8336 and $M$ 7908) and the conventional soybean cultivars (FD 39, CD 217, CD 205, IAC Foscarin, FT Cristalina, BRS 183, BRS Sambaíba, BRS Conquista, BRS Tucunaré and BRS Renascença). This differentiation was seen because none of the plants of the conventional cultivars survived the application of glyphosate. On the other hand, all the plants belonging to the group of transgenic cultivars survived.

In conventional soybean, glyphosate inhibits the enzyme, 5-enolpyruvylshikimate-3-phosphate synthase (EPSPS), which is essential in the metabolic pathway for the synthesis of amino acids and also of some secondary metabolites; resulting in growth suppression and the subsequent death of the plant (QUERCI et al., 2010). The phytotoxic effects were not pronounced in the RR soybean, as vegetative growth continued in the affected plants; this being due to genetically modified plants having the herbicideresistant gene, which enables their development and the formation of normal seedlings (FUNGUETTO et al., 2004).

Use of the toothpick technique made it possible to adopt a rating scale (1 to 9) to compare the reaction of the cultivars to the effects of glyphosate and to differentiate between them (Table 1). Separation of the cultivar reactions was based on the percentage of dead leaves or those showing symptoms of wilting and yellowing over the evaluation period.

In the first days of the evaluation (2, 4 and 6 DAA), a significant difference was seen at a level of 5\% among cultivars of the conventional group, whereas in the later evaluations (8 and 10 DAA), the test was not significant, i.e. no differences could be seen between the treatments, since as expected, the conventional group does not tolerate the effects of glyphosate application (Table 1).

The cultivar, BRS Tucunaré, was the most susceptible to the effects of glyphosate, with the highest mean values by t-test (Table 1), and consequently the highest ratings on the diagrammatic scale on the first day of evaluation. It is important to note that for all treatments, the symptoms of toxicity consisted in general of chlorotic spots, shortening of the veins and wrinkling of the leaves, followed by death.

Among the group of transgenic cultivars, there was a significant difference at a level of $5 \%$ for the whole period of evaluation. This was due to differences in levels of sensitivity to the effects of the herbicide. The cultivar, BMX Potência, stood out as more susceptible to the effects of glyphosate on the five days of evaluation (2, 4, 6, 8 and 10 DAA), having the highest mean values by t-test. Conversely, the M 8336 cultivar had the lowest mean values, being considered the best of the transgenic group (Table 1).

From the diagrammatic scale used for rating phytotoxicity, it was possible to differentiate the transgenic cultivars into different levels of susceptibility, highlighting five groups: highly sensitive (BMX Potência), moderately sensitive (TMG 4001, P98Y70 and CD 242), sensitive (EMGOPA 315, NA 6411 e BRS Juliana), moderately tolerant (SYN 9078 and M 7908) and tolerant (M 8336) (Figure 2).

The application of glyphosate caused yellowing and discoloration of the leaves of the transgenic cultivars during the first days after application; the injuries decreasing over time, with full recovery for most plants by day 10 of herbicide application. From this it is possible to infer that the symptoms caused by glyphosate were only localised, as the injured plants continued growth of the main stem, developing new lateral branches. In the same way, Reis et al. (2010) concluded that high doses of glyphosate, irrespective of the formulation used, caused injury to the leaves, which can be considered to be a symptom of phytotoxicity. However, if the environmental and nutritional conditions are favourable, the plants develop normally, including the development of other leaflets, which may not significantly interfere with the development of the plants.

In a similar study, Krausz and Young (2001) reported that glyphosate caused more pronounced chlorosis in the leaves when applied at the $\mathrm{R} 1$ reproductive stage of the soybean, which was intensified with the increasing dosages used. However, symptoms remained restricted to leaves that had received the product, with new leaves showing no signs of injury.

According to the results obtained in this study, efficiency of the toothpick method in detecting transgenic soybean was observed, the method enabling the differentiation of the transgenic soybean cultivars from the conventional cultivars, and showing itself to be an efficient, simple and objective technique.

However, a lack of studies using this methodology was found in the literature, demonstrating the importance of conducting more research into this subject.

To confirm the results obtained by the toothpick method, the PCR technique was used to amplify the EPSPS coding region in transgenic crops, and thereby identify them.

The results of DNA amplification using the RR oligonucleotides, showed that the transgenic soybean samples determined bands which were a consequence of the specific amplification of the target DNA with 172 base pairs, while samples of conventional soybean did not determine the amplification of this DNA sequence (Figure 3). PCR analysis confirmed the results obtained with the toothpick test, in which 
the conventional plants died due to the lack of the EPSPS gene, which encodes tolerance to the herbicide, glyphosate. Similarly, Lin, Chiang and Shih (2001) and Conceição, Moreira and Binsfeld (2006) found that the PCR method was effective in distinguishing RR from conventional soybean.

The polymerase chain reaction (PCR) is the analysis which is most used in the detection of GMOs, due to its high sensitivity and specificity in DNA amplification (DINON et al., 2010; MARMIROLI et al., 2008; MICHELINI et al., 2008). Furthermore, it is an important tool in the case of a re-test, when there is doubt about the detection of transgenic organisms by other methodologies (CUNHA et al., 2005). However, the technique requires sophisticated equipment, costly reagents, specialised labour, and time in order to achieve results ( 2 to 3 days).

Factors such as cost, specificity, accuracy and speed should be considered when choosing the best methodology for the detection of GMOs (CONCEIÇÃO; MOREIRA; BINSFELD, 2006). In seed-analysis laboratories, detection of transgenic samples is carried out with the test for herbicide resistance conducted together with the germination test, known as the bioassay (AYALA et al., 2002). The bioassay for tolerance to herbicide is a simple, practical and fast method, in which the target seeds are placed on a germination medium containing

Table 1 - Reaction of transgenic and conventional soybean cultivars submitted to the toothpick test with glyphosate on day ten of evaluation

\begin{tabular}{|c|c|c|c|c|c|}
\hline \multirow{2}{*}{ Cultivar } & 2 & 4 & 6 & 8 & 10 \\
\hline & \multicolumn{5}{|c|}{ 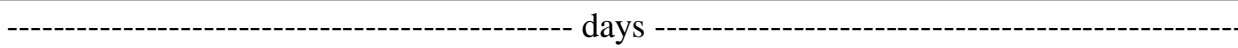 } \\
\hline \multicolumn{6}{|c|}{ 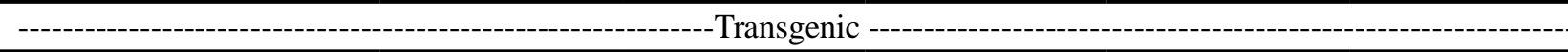 } \\
\hline BMX Potência & $5.48 \mathrm{a}$ & $6.17 \mathrm{a}$ & $5.90 \mathrm{a}$ & $5.62 \mathrm{a}$ & $5.34 \mathrm{a}$ \\
\hline TMG 4001 & $5.13 \mathrm{a}$ & $5.53 \mathrm{ab}$ & $5.73 a b$ & $5.40 \mathrm{ab}$ & $5.37 \mathrm{a}$ \\
\hline NA 6411 & $4.77 \mathrm{a}$ & $5.17 \mathrm{ab}$ & $4.83 \mathrm{abc}$ & $4.57 \mathrm{abc}$ & $4.30 \mathrm{ab}$ \\
\hline BRS Juliana & $4.48 \mathrm{bc}$ & $5.35 \mathrm{ab}$ & $4.04 \mathrm{~cd}$ & $3.30 \mathrm{def}$ & $3.48 \mathrm{bcd}$ \\
\hline P $98 Y 70$ & $4.40 \mathrm{bc}$ & $5.56 \mathrm{ab}$ & $5.08 \mathrm{abc}$ & $4.64 \mathrm{abc}$ & $4.40 \mathrm{ab}$ \\
\hline CD 242 & $4.29 \mathrm{bc}$ & $4.93 \mathrm{~b}$ & $4.68 \mathrm{bcd}$ & $4.40 \mathrm{bcd}$ & $4.04 \mathrm{bc}$ \\
\hline EMG 315 & $3.63 \mathrm{dc}$ & $4.63 \mathrm{bc}$ & $4.53 \mathrm{~cd}$ & $4.30 \mathrm{bcde}$ & $4.23 \mathrm{ab}$ \\
\hline SYN 9078 & $2.80 \mathrm{~d}$ & $3.60 \mathrm{~d}$ & $3.90 \mathrm{~d}$ & 3.17 ef & $2.87 \mathrm{~cd}$ \\
\hline M 8336 & $1.80 \mathrm{e}$ & $2.97 \mathrm{~d}$ & $2.80 \mathrm{e}$ & $2.63 \mathrm{f}$ & $2.47 \mathrm{~d}$ \\
\hline M 7908 & $1.67 \mathrm{e}$ & $3.67 \mathrm{dc}$ & $3.80 \mathrm{de}$ & $3.57 \mathrm{cdef}$ & $3.93 \mathrm{bc}$ \\
\hline F (Cultivars) & $14.92 *$ & $8.07 *$ & $6.16^{*}$ & $5.46^{*}$ & $4.29 *$ \\
\hline $\mathrm{CV} \%$ & 49.59 & 41.43 & 45.15 & 54.29 & 60.85 \\
\hline \multicolumn{6}{|c|}{ - } \\
\hline FD 39 & $2.20 \mathrm{de}$ & $6.73 \mathrm{c}$ & $7.90 \mathrm{bc}$ & $8.83 \mathrm{a}$ & $8.83 \mathrm{a}$ \\
\hline CD 217 & $1.87 \mathrm{e}$ & $5.67 \mathrm{~d}$ & $7.87 \mathrm{bc}$ & $8.77 \mathrm{a}$ & $8.87 \mathrm{a}$ \\
\hline CD 205 & $1.77 \mathrm{e}$ & $5.37 \mathrm{~d}$ & $7.93 \mathrm{bc}$ & $9.00 \mathrm{a}$ & $9.00 \mathrm{a}$ \\
\hline IAC Foscarim & $2.63 \mathrm{~d}$ & $6.70 \mathrm{c}$ & $8.00 \mathrm{~b}$ & $9.00 \mathrm{a}$ & $9.00 \mathrm{a}$ \\
\hline FT Cristalina & $1.93 \mathrm{de}$ & $6.85 \mathrm{bc}$ & $8.00 \mathrm{~b}$ & $9.00 \mathrm{a}$ & $9.00 \mathrm{a}$ \\
\hline BRS 183 & $1.77 \mathrm{e}$ & $6.43 \mathrm{c}$ & $7.60 \mathrm{c}$ & $8.60 \mathrm{a}$ & $8.77 \mathrm{a}$ \\
\hline BRS Sambaíba & $4.73 \mathrm{c}$ & $7.96 \mathrm{a}$ & $8.65 \mathrm{a}$ & $8.73 \mathrm{a}$ & $8.77 \mathrm{a}$ \\
\hline BRS Conquista & $2.30 \mathrm{de}$ & $6.63 c$ & $7.82 \mathrm{bc}$ & $8.74 \mathrm{a}$ & $8.78 \mathrm{a}$ \\
\hline BRS Tucunaré & $6.30 \mathrm{a}$ & $7.93 \mathrm{a}$ & $8.77 \mathrm{a}$ & $8.77 \mathrm{a}$ & $8.77 \mathrm{a}$ \\
\hline BRS Renascença & $5.58 \mathrm{~b}$ & $7.38 \mathrm{ab}$ & $8.77 \mathrm{a}$ & $8.96 \mathrm{a}$ & $9.00 \mathrm{a}$ \\
\hline $\mathrm{F}$ (Cultivars) & $45.61 *$ & $14.52 *$ & $9.22 *$ & $0.95^{\mathrm{ns}}$ & $0.74^{\mathrm{ns}}$ \\
\hline $\mathrm{CV} \%$ & 44.51 & 17.74 & 9.22 & 8.82 & 7.57 \\
\hline
\end{tabular}

*significant at $5 \%$; ${ }^{\text {ns }}$ not significant; mean values followed by the same letter in a column do not differ by t-test at $5 \%$ probability 
Figure 2 - Reaction of transgenic cultivars for symptoms of phytotoxicity

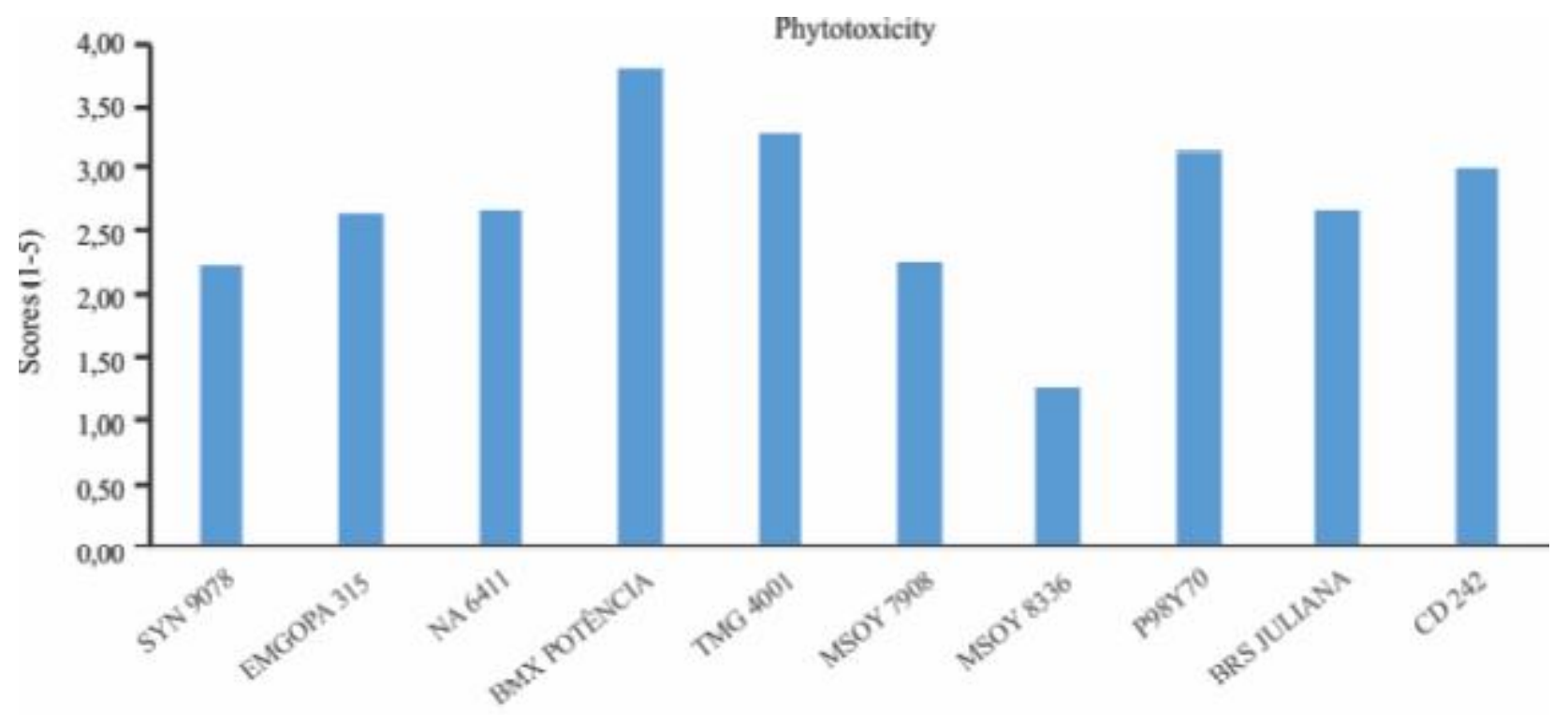

Cultivars

Figure 3 - Results of DNA amplification using the RR oligonucleotide of $172 \mathrm{bp}$ of the ten transgenic and ten conventional soybean cultivars

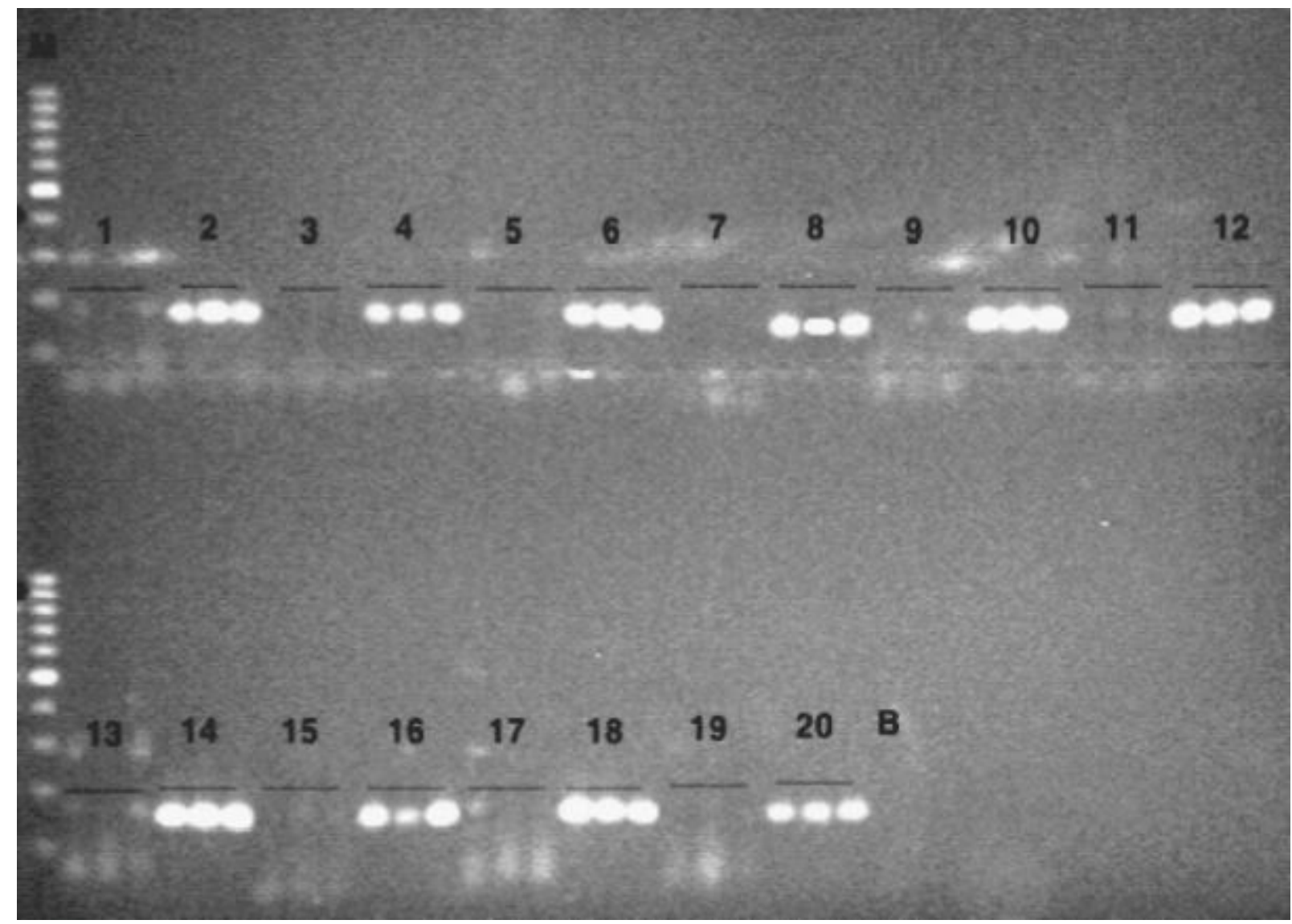

M: molecular weight marker 100 bp DNA Ladder; conventional cultivars - 1 (BRS Tucunaré), 3 (BRS Sambaíba), 5 (BRS 183) ,7 (BRS Renascença), 9 (BRS Conquista), 11 (CD 205), 13 (FD 39), 15 (IAC Foscarim), 17 (FT Cristalina) and 19 (CD 217); transgenic cultivars - 2 (BMX Potência), 4 (M 7908), 6 (TMG 4001), 8 (SYN 9078), 10 (NA 6411), 12 (BRS Juliana), 14 (P 98Y70), 16 (M 8336), 18 (CD 242) and 20 (EMG 315) 
a dilute solution of the herbicide, and development of the seedlings is observed. They are not however used in breeding programs because they are performed exclusively on the seeds, and require a long time to get results. Bioassays are currently much used by companies which export grain and seed (TORRES et al., 2003).

The toothpick methodology is a useful tool in the detection of transgenic plants for soybean breeding programs, as it is an accurate and cheap test, one which is easy to carry out and which can be performed directly in the field or in the greenhouse without damaging the adjacent plants by the process of drift. It also does not require specialised labour or sophisticated equipment, and generates results varying from 4 to 8 days after implementation of the test.

\section{CONCLUSIONS}

The toothpick test is effective in identifying soybean plants which carry the gene for resistance to glyphosate (RR). In addition, among genetically modified cultivars, the method allows differentiation of groups which are defined according to their sensitivity to phytotoxic symptoms.

\section{REFERENCES}

AYALA, L. et al. Tetrazolium test for identification of transgenic rice seeds tolerant to herbicide. Seed Science and Technology, v. 30, n. 2, p. 431-436, 2002.

BERVALD, C. M. P. et al. Desempenho fisiológico de sementes de soja de cultivares convencional e transgênica submetidas ao glifosato. Revista Brasileira de Sementes, v. 32, n. 2, p. 009-018, 2010

CÉLERES. $2^{\circ}$ levantamento de adoção da biotecnologia no Brasil, safra 2013/14. 2013. p. 7. Disponível em: <http://celeres. com.br/wordpress/wp-content/uploads/2013/ 12/IB13021.pdf > Acesso em: 28 jan. 2014.

COMPANHIA NACIONAL DE ABASTECIMENTO. Acompanhamento da safra brasileira de grãos. $4^{\circ}$ Levantamento Grãos Safra 2013/14-Janeiro 2014. Disponível em: <http://www. conab.gov.br/OlalaCMS/uploads/arquivos/14_01_10_15_07_19_ boletim_graos_janeiro_2014.pdf $\geq$. Acesso em: 28 jan. 2014.

CONCEIÇÃO, F. R.; MOREIRA, A. N.; BINSFELD, P. C. Detecção e quantificação de organismos geneticamente modificados em alimentos e ingredientes alimentares. Ciência Rural, v. 36, n. 1, p. 315-324, 2006.

CUNHA, C. S. M. et al. Comparação de métodos na detecção de sementes de soja geneticamente modificada resistente ao glifosato. Revista Brasileira de Sementes, v. 27, n. 1, p. 167-175, 2005.

DINON, A. Z. et al. Monitoring of GMO in Brazilian processed meat and soy-based products from 2007 to 2008. Journal of Food Composition and Analysis, v. 23, n. 3, p. 226-229, 2010.
EMPRESA BRASILEIRA DE PESQUISA AGROPECUÁRIA. Tecnologias de produção de soja - Região Central do Brasil, 2012 e 2013. Londrina: Embrapa Soja, 2011. 261 p.

FERREIRA, M. E.; GRATTAPAGLIA, D. Introdução ao uso de marcadores RAPD e RFLP em análise genética. Brasília: EMPRAPA-CENARGEN, 1995.220 p. (EMBRAPACENARGEN. Documentos, 20).

FUNGUETTO, C. I. et al. Detecção de sementes de soja geneticamente modificada tolerante ao herbicida glifosato. Revista Brasileira de Sementes, v. 26, n. 1, p. 130-138, 2004.

HEINZ, R.; VIEGAS NETO, A. L.; VALENTE, T. O. Detecção de sementes de soja geneticamente modificada por meio de teste de germinação. Revista Agrarian, v. 4, n. 11, p. 20-26, 2011.

HUANG, Y. H.; HARTMAN, G. L. Reaction of selected soybean genotypes to isolates of Fusarium solani f. sp. glycines and their culture filtrates. Plant Disease, v. 82, n. 9, p. 999-1002, 1998.

KRAUSZ, R. F.; YOUNG, B. G. Response of glyphosateresistant soybean (Glycine max) to trimetylsulfonium and isopropylamine salts of glyphosate. Weed Technology, v. 15, n. 4 , p. $745-749,2001$.

LIN, H-Y.; CHIANG, J-W.; SHIH, D-Y. C. Detection of Genetically Modified Soybeans by PCR Method and Immunoassay Kits. Journal of Food and Drug Analysis, v. 9, n. 3, p. 160-166, 2001.

MARCELINO, F. C.; GUIMARÃES, M. F. M.; BARROS, E. G. Detecção e quantificação de alimentos geneticamente modificados: o panorama brasileiro. Revista Ceres, v. 54, n. 313, p. 240-250, 2007.

MARMIROLI, N. et al. Methods for detection of GMOs in food and feed. Analytical Bioanalytical Chemistry, v. 392, n. 3, p. 369-384, 2008.

MARTINS, M. C. et al. Escala Diagramática para a quantificação do complexo de doenças foliares de final de ciclo em soja. Fitopatologia Brasileira, v. 29, n. 2, p. 119-184, 2004.

MICHELINI, E. et al. New trends in bioanalytical tools for the detection of genetically modified organisms: an update. Analytical Bioanalytical Chemistry, v. 392, n. 3, p. 355-367, 2008.

PADGETTE, R. et al. Development, identification, and characterization of a glyphosate-tolerant soybean line. Crop Science, v. 35, n. 5, p. 1451-1461, 1995.

QUERCI, M. et al. New approaches in GMO detection. Analytical Bioanalytical Chemistry, v. 396, n. 6, p. 1991-2002, 2010.

REIS, T. C. et al. Efeitos de fitotoxidade na soja RR tratada com formulações e dosagens de Glifosato. Revista de Biologia e Ciências da Terra, v. 10, n. 1, p. 34-43, 2010.

STATISTICAL ANALYSES SYSTEM. Institute SAS. The SAS System, release 9.2. Cary: NC, 2008.

TORRES, A. C. et al. Bioassay dor detectetion of transgenic soybean seeds tolerant to glyphosate. Pesquisa Agropecuária Brasileira, v. 38, n. 9, p. 1053-1057, 2003. 